\title{
Die Tweede Vatikaanse Konsilie
}

Dit is enigsins 'ה waagstuk om 'n beoordeling van Rome te gee na die 2de Vatikaanse Konsilie. Die moeilikheid is veral dit dat baic van die besluite wat daar geneem is ietwat vaig en soms dubbelslagtig van karakter is sodat dit op verskillende. soms selfs teenstrydige. maniere uitgelê of verklaar kan worc!

Die feit is dat die lug nie gesuiwer is Jeur die Konsiliebesluite nie, maar dat dit eerder aanleiding was tot nog groter verwarring en dat dit werklik moeilik is om uit dic verskillende interpretasies altyd presies vas te stel watter nou die egte, outentieke stem van die RoomsKatolieke Kerk is.

In ..Internationale Kirchliche Zeitschrifi” word byvoorbeeld gewys op 'n rondskrywe van Kardinaal Otlavisni. hoof van die Kongregasic vir die geloofsleer (die vroec̈re ... Ieiligen Offizium"), onder goedkeuring van Pous Paulus, aan die voorsitters van Biskopkonferensies en die owerstes van die verskillende religieuse Orles, waarin gevra word dat pogings aangewend moet word om ..der missbrüuchlichen Interpretation der Lehre des Konzils, und der sehr gewagten Meinungsäusserungen einzelner" teë te gaan. Onder hierdie verwarrende en misduidende interpretasies in Roomse hringe word dan li) punte genoem, waaronder: (1) Die onfeilbaarheid van die Skrif en die verhouding tot die Tradisie; (2) die gesag van dogmatiese formuleringe; (3) die leeramp van die Biskoppe en die Pous; (4) die Godheid van Christus en Sy wonderwerke; (5) die Sakramente (neiging tot simbolisme): (6) die boete; (7) die erfsonde; (8) situasie-etiek; en (9) ekumenisiteit. ${ }^{1}$ Dinge lyk dus in die Roomse wêreld net so op dic helling soos in die Protestantse wêreld.

Die tweede Vatikaanse Konsilie van die Rooms-Katolieke Kerk het 16 dokumente aanvaar, in hul sitting wat vanaf 1961.65 geduur het. Daar is vier konstitusies (leerstellig van aaru), 9 dekrete (metr prakties) en 3 verklaringe (van aktuele betekenis)." In De Reformatie gee $F$. de Vries verskillende meninge oor lie Konsilie. wat interessant is om van kennis te neem. Volgens sommine Roomse beoordelaars het die Rooms-Katolieke Kerk nou gebreek met die Middelecue. Sommige sê dis die end van die Kontra-reformasie. Andere verklaar dat Rome uiteindelik die 20ste ceu binnegegaan he. Dit word ook genoem .Begin van een nieuw tydperk in de historie van het Christendom".

Dit blyk dat die konserwatiewe minderheid $15 \%$ was, egter sterk verteenwoordig in die Kurie. Die biskoppe het nou meer betekenis gekry en hulle mag nou regionale konferensies hou. Hulle word beskou as opvolgers van die apostels. Hul besluite is egter onderhewig aan Pouslike goedkeuring.

In die Rooms-Katolieke blad ... Die Brug", wat baie progressief is, word verklaar: „Dil kan ook nie on!ken word dat dic Konsilie vir 
baie Katoliekc en Reformatoriese Christene in baic opsigte teleurstellend was nie. Waar (laar meer as $2.5(x)$ kerkvaders van oor die hele wêreld byeengekom het ... kon dit wel nie anders of die uiteindelike redaksie van die Dekrete... moes noodwendig soms vaag en verwater te voorskyn kom nie“. Verder sê die blad: ..Die Pous het ook etlike male persoonlik ingegryp en veranderings in die tekse of ,verklarencle note' aangebring teen die wense van die meerderheid van die Konsilielede van die gesamentlike biskoppe". Desnieteenstaande meen Die Brug dat die Konsilie 'n aansienlike ..hatige saldo" afgewerp het en verklaar dan dat die totalc beeld van die kerk ná die Konsilie een van totale vernuwing is. ${ }^{3}$

Die hoof van die L.utherse Kerk in Hongarye. Biskop I ajos Veto. het in Budapest by die ... ieneralversammlung" verklaar dat Rome wel iaat blyk het dat hulle behoefte het aan reformasie van die RoomsKatolieke Kerk. maar dat wat sover gebeur het. in vergelyking met wat volgens die Evangelic noodsaaklik is, baie weinig is. Die Geref. Biskop, dr. T. Bartha, het by 'n ander vergadering verklaar ..dasz die römisch-katholische Kirche von ihrem im Tridentinum begangenen und auf den Ersten Vatikanischen Konzil widerholten Irrtumeren. die seit der Gegenreformation bis in unsere Tagen in aller Welt und nicht zuletzl auch fiir den ungarischen Prolestantismus unermeszliches l eid verursacht haben, noch nichts aufgegeben hat"."

Interessant vir dic Rooms-Katolieke gees is die voorbede wat vanjaar (1966) deur die diosees van Rome vir die ..Gebeclsoktaaf vir die eenheid van die Christene" uitgeskryf is: .Wir bitten für die Anglikaner, auf dasz die katholische Tradition die im Anglikanismus fortlebt. zunehmen und schliezlich die Oberhand gewinnen möge, damit sie wieder zur Anerkennung des Papstes, des Stellvertreters Christi. geführt werden ..." In die voorbede vir die Protestante word die wens uitgespreek dat hulle die kerk van Romie onder die heerskappy van die Pous en die Hierargic as dieselfde Kerk sal erken, wat op Pinksterdag gegrond is en dat hulle derhalwe sal insien dat die verering van Maria ..eine authentische Fortentwicklung der Botschaft des Evangeliums darstelle".

Wat die posisie van die Roomse Pous betref. wys Paul Verghese daarop dat in die dogmatiese Konstitusic oor dic Kerk (.,Lumen Gen. (ium") verklaar is dat, om dic eenheid van die amp te bewaar. Christus vir Petrus oor dic ander apostels geplaas het en hom gestel het as in permanentc en sigbare fondament van geloofscenheid en gemeen. skap. Hy haal dan verder aan: ..But the college or body of bishops has no authority unless it is understood together with the Roman Pontiff. the successor of Peter as its head ... In virtue of his office. that is as Vicar of Christ and pastor of the whole Church. the Roman Pontiff has full. supreme and universal power over the Church. And he is always free to exercise this power... A council is never ccumenical unless it is confirmed or at least accepted as such by the successor of Peter and it is the prerogative of the Roman Pontiff to convoke these councils, to preside over them and to confirm them"." 
Verghese ŝ̃ dit toon die wye gaping wat daar is tussen Rome en die Wêreldraad van kerke t.o.v. die kwessie van die eenheid van die Kerk. ..and I do not know of one single member of the Church in the World Council which would accept these formulations without radical qualification": Daarom meen ons ook dat die ..Christian Minister" in sy .Editorial" seker nie te ver gaán as hy sê dat by Rome die onfeilbaarheid van die Kerk so nou can die Pous verbind is dat dit alleen deur rom bestaan en sonder hom verdwyn. en dat, na die 2de Vatikaanse Konsilie, ,the Pope has in fact emerged stronger than ever".

Prof. Subilia som die Rooms-Katolieke beleid op as 'n beleid van integrasie". Waardes wat in nie-katolieke kringe gevind word. word in die Rooms-Katolieke konteks geinkorporeer. Subilia noem sulke dinge soos: die plek wat aan die Skrif gegee word; die gebruik van die volkstaal; dic betekenis van die prediking teenoor die sakramentsverskaffing van rroeër; die idee van die algemene priesterskap van die leke; die kollegiale gedagte i.v.m. die verhouding van Pous en Biskoppe; meer openheid t.o.v. die Ekuméne." ens. Subilia wys egter daarop dat dit duidelik is dat datar vanuit dic Katolieke visie geen verandering kan kom in die e.ssensiële konsepsie en fundamentele struktuur van die Kerk nie, soos Paulus VI verklaar het in sy Encikliek: ..Ecclesiam suam": verder dat kardinaal Bea uitdruklik verklaar het dat geen dogmatiese stellinge gewysig of nietig verklair sal word, wat reeds tevore vasgelê is, of enige leerpunte wat tevore veroordeel is nou aanvaar sal word nie. "What is intended is the unlımited amplification of the synthesis, extending it not only to Protestants, but also to the non-Christian religions and finally to non-helievers, as is demonstrated by the erection of the appropriate secretariats alongside that for Christian unity." sê Subilia."

Teenoor die nuwe Romanisme wil Subilia in bolwerk opwerp deur die sola fide-sola gratia van die Reformasie. wat hy egter in Barthiaanse trant uitwerk. Ons sou dus, volgens hom, sonder enige sekerheid of vastigheid moet beweeg in die rigting van die Waarheid. maar is nooit die .gelukkige besitters" daarvan nie. Waarlik, hiermee glo ons het ons die stryd teen Rome verloor voordat ons dit begin het en speel ons juis in die hande van Rome. Die krag en sterkte van die Reformasie was dat dit die Heilige Skrif as gesagsinstansie teenoor Rome en sy Pous gestel het ell die Protestantisme het sy eie graf gegrawe toe hy die Skrif aan die kritiek van menslike insigte gaan prysgee het en die menslike .wysheid" bokant (iods Woord gaan verhef het.

In verband met lie 2de Vatikaanse Konsilie mag daar verder ook op gewys word dat daar tog wel enige aksentsverskuiwing in die Roomse kerkidee plaasgevind het. Prof. Reid wys daarop dat die idee van die Kerk as ..volk van God" voorrang verkry het bo die idee van die Kerk as ..liggaam van Christus". By die liggaamsidee kom die hierargiese struktuur (hoof en lede) meer na vore, terwyl by die volksidee die algemene priesterskap en die gemeenskap van die gelowiges meer prominent is." Dit, sê Reud. het ook ekumeniese konsekwensies, aan- 
gesien die Kerk. as rolk van God. nou wyer as dic Roomse instituut gesien word en ander Kerke ook op n defekte wyse deel het aan die Kerk van Christus." " Maar dan wys Reid ook daurop dat hieıdie breëre kerkopvatling tog weer in die hiërargiese struktuur geplaas word. Van Christus af loop die kerk cor Petrus. die apostels. Pous en biskoppe na die gewone priesterskep. ${ }^{13}$ Eintlik is alle amptelike gesag in die Pous gekonsentreer. En selts waar Vatikaan 11 nou ook klem laat val het op die idee van kollegialiteit. naanlik die Pous met die biskoppe. bly hulle maar net adviserend. Die Pous kan hulle oproep. as hy wil. on onder s $v$ voorsitterskap te vergader en sake te bespreek wat hy goedvind. Kardinale ells., is ramself lid van so in biskoplike kollege; die biskoppe moet egter as atgevaardigdes gekies word en die Pous moet hulle afvaardiging goedkeur; ook mag hy andere benoem. wat hy daar wil hê." So "n Biskopssinode het dus geen beslissende mag nie. maar bly in blote adviserende liggaam. Daarom verklaar prof Reid dat dii duidelik is dat die kloof lussen die Kerkvolk en die priesterstand nog geensins gedemp is nie. Die priesterskap ...is still a class absolutized. from which the Church depends" ${ }^{1 . "}$ En hierby wil ons dan net voeg dat. Waar daar in ekumeniese pogings vandag deur baie uit Protesiantse kringe die biskoplike stelsel weer met soveel klem bepleit word. juis on die pad oop te maak na uiteindelike eenwording met Rome. ons dan ouk daarop moet let dat dit by Rome nie in bloot formele kerkregtelike beginsel is nie. maar dat Rome daarin die wese van die kerk self sien. naamlik $n$ kerk wat feitlik die voortgeselte inkarnasie van Christus is. waarby die Pous dan eintlik vir Christus verteenwoordig en al die ander lede van die kerk alleen maar via die Pous aan Christus deel kan kry.

Daar is. veral in Nederland, maar ook in lande soos Frankryk en Duitsland, byvoorbeeld. wel sterk neigings van Roonse toenadering tot die Protestantisme, soos ook blyk uit die boek van Berkhouwer: ..Vatikaans Koncilie en nieuwe theologie"."16 In Nederland hoor "in mens werklik interessante opvattinge veral by in man soos prof. Schillebeeckx van Nymegen. Ons wil iets daarvan meld, volgens in gesprek wal dr. Arts met Schillebeeckx gevoer het."

Schillebreckx sì dat daar nog geeksperimenteer word met dic Misliturgie. Dit neig in die ripling dat die hele $M$ is in die volkstaal gebruik sal word. selfs die kanengedeelte. wat nou nog in Latyn is. Verder sề hy dat Christus nog vel in die Eugaristie as ..teenwooruig" gesien word. maar hoe hy presies in die brood en wyn is. bly "n misteric. Materiele verandering van die brood en wyn in vlees en bloed word nie meer so direk verbind nie. In plaas van Transsubstansiasie wil Schıllebeeckx liewer ...Transfigurasie" of ..Transsignifikasic" gebruik. Nogtans ineen Schillebeckx dat "n Roomse lidnaat nie aan in Protestantse nagmaalsviering kan deelneem nie, ondat die leenwoordigheid van (hristus daar anders gesien word.

In sake die Misviering vind ons we! by dic 2de Vatikaan enige verbeteringe en toenatering tot die Protestantse beshouing. maar oor. hier weer is die hele posisie vadg. veral toov. die kernvraag van die 
wyse warop Christus teenwoordig is in die sakramentele tekens. In in insiggewende artikel van dr. C. P. T. Ryper oor die Encikliek van Paulus VI. Mysteriun Fidei, 3 Sept., 1965, bespreek hy die Ensikliek teen die agtergrond van die besluite van die 2de Vatikaanse Konsilie." Dit blyk dat daar veral in Nederlano onder die biskoppe 'n neiging is om die transsubstansiasiegedagte nie meer so realisties te wil aanvaar nie. Hulle slui! hul aan by die gedagte van Pous Johannes XXIII wat die Konsilie opgeroep het dal. alhoewe! die Kerkleer in geen opsig gewysig mag word nie, daar tog onderskei moet word tussen die sake self en die wyse of modus waarop dit, veral by Trente, ingeklee was: .aliud est enim depositum fidei, aliud est modus". Dit gaan dus nic om die reële presensie van Christus by die nagmaal nie, maar wel hoe Hy daar teenwoordig is.

Nou toon Ryper aan uit dic Ensikliek van Paulus VI dat hierdic onderskeiding as ontoelaatbaar ieskou word."' Hy wys daarop dat die Konsilie in Constitutio II dic nagmaal ook noem "n ,.mysterium ¿idei" en dat daar dan verklaar word dat die lidmate dit nie moe! vier soos buitestanders en swyende toeskouers nie. maar dat hulle onderrig moet word om welbewus en gedvrugtig daaraan deel te neem. Dic lof up die private $M i s$ en die devosie van die Eugaristie word hier nic beklemtoon nie. Daar moet gepreek word en die volkstaal moet gebruik word, sodat die leke kan weet en verstaan wat aangaan.

Daarteenoor, sê Ryper. worł nou in die Ensikliek weer beklcmtoon dat die private misse nie onderskat of nagelaat moet word nie. Verder verklaar die Ensikliek dal die geheim van die transsubstansiasic inhou die wonderbare verandering van heel die substansie van die brood in die Liggaam en heel dic substansie van die wyn in die Bloed van Christus. " $"$ Die konsekreerile hostie is en bly die vlees en bloed van Christus, selfs na die nagmaalsviering en Jaarom mag en moet die hostie dan as Christus self vereer en aanbid word."1 $R$ yper sê dat Kuitert hierdie Ensikliek oor die Eugaristie beskryf het as ..de hardste klap voor de $\mathrm{zg}$. nieuwe theologie, die we tot nu toe hebben meegemaakt"."'

Ryper wys daarop dat sowel die Ensikliek as die Konstitusie oor die nagmaal spreek as ' $n$ misteric of geheimenis. In die Konstitusie word dan ook gesê dat Christus aanwesig is in die Misoffer, sowel in die persoon van dic bedienaar as in die eugaristiese elemente. Hy is aanwesig in die sakramente. in sy Woord en ook in die kerk wat smeek en lofsing (Konst. 7). Hierdie gedagtes, sê Ryper, vind ons ook in die Ensiklıek. Maar hier word tog benalruk dat in die Nagmaal Christus substansieel teenwoordig is. Hier is Christus. (jol en mens, totaal en volledig teenwoordig. ${ }^{23}$ Die Ensikliek verklaar dat in die nagmaal Christus daadwerklik geoffer word en daarom moet aanvaar word dat die lekens subsiansieel en objekticf verander word in iels wat outologies anders is. .Immers onder de genoemde gedaanten is niet meer. wat er eerst was. maar iets geheel anders en dit niet alleen op grond van het geloofscordeel der kerk, maar in de objectieve werkelijkheid".:" 
In verband met Schıllebeeskx meen hy verder dat ,papalisme" 'n kettery is en dat ons nie mag itanvaar dat alle Christene onder die oppergesag van die Pous staan nie. Ook die Pous staan onder die kritiese toets van die Bubel. Ekumenisiteit kan alleen daarin gevind word dat ..alle Kerke terug moet keer na die evangeliese boodskap". Hy meen selfs dat die Prolestante die ,evangeliese boodskap" van die Bybel beter bewaar as die Roomse, maar dan sal die Protestante moet loskom van die Bybelse ..magie". net soos Rome besig is om los te kom van die ..magie" van die amp. Hy meen egter dat daar 'n meer .oop" houdling moet wees t.o.v. Wat die Skrif leer. Hy wil skynbaar opening laat vir 'n mate van Skrifkritiek. Vir hom is dit nie die kerklike gesagsdraers nie. maar die kerk as geheel. as die Volk van God. wat die onfeilbare gesag dra on dogmas neer te lê. Hy beskou dit van fundamentele betekenis dat die Kerk nou gesien word as ,.die volk van God" en nie, soos in die verlede, in die eerste plek as dic hierargie en die priesterstand nic. Daar het in herwaardering gekom van die algemene amp of priesterskap van die gelowiges. Wel word die Kerk .gelei" deur die Pous en biskoppe. Die biskopsamp is nou nie meer soseer 'n magsposisie nie as wel een van diens. Die biskoppe. insluitende die Pous, is almal opvolgers van die apostels. Dis wel nie uitdruklik verklaar dat die Pous gedurig rekening moet hou met die biskopskollege nie. maar deur die kollegialiteit is die biskoppe nie louter dienaars of amptenare van die Pous nic. maar behoort hulle in die algemenc bestuur van die kerk ingeskakel te word. Schille. beeckx meen dat hierdie saak on in derde Vatikaanse Konsiiie verder gevoer sal word. 'n Pous hoef. volgens hom, ook nie lewenslank aangestel te word nic; hy sou ook eenvoudig as president van die biskopskollege kan optree

Daarenteen wys W. Küppers van die Ou-Katolieke Kerk op die feit dat in die Konstitusie ..de Ecclesia" die "Tweede Vatikaanse Konsilie herbeklemtoon het dat die Kerk gesien moet word vanuit die blywende en sigbare geloofs- en gemeenskapseenheid wat in die Pontifikale anp van die onfeilbare Pous sy fondament en beginsel het.:i en dat juis hier nog ' $n$ onoorbrugbare kloof tussen Rome en die OuKatolieke lê. Die Pous, en hy alleen. is I Iniversaal-Biskop en mondstuk van die Kerk.-"- Dat die Kerk die Pous se besluite moet aumaur of toestem. sê Küppers. maak geen wesenlike verskil aan sy gesag nie."7 Die Ou-Katolieke Kerk (met wie die Anglikaanse Kerk verband het. S. J. v.d. W.) bly, volgens küppers dus nog die middleweg tussen Westerse en Oosterse Katolisism:."

Die vraag i.v.m. die magsposisic van die Pous is of die Kerk (i.c. die Pous) inderdaad onder die kritiese toets van die Bybel staan. soos Schillebeeckx sê. en of hy dalk bokumt die Skrif staan en daaroor heers? Is die Skrif self 'n stuk van die Tradisie van die Kerk en moet dic Pous nou uitmaak en bepaal wat die Tradisic eintlik is. m.a.w. Wat die boolskap van die Skrif is en hoe dit geïnterpreteer moet word? Daarom is dit belangrik on te let op wat die 2 de Vatikaanse Konsilic se houding is t.o.v. die kwessic van Skrif en Tradisie. 
George Tavard, 'n lid van die Roonse Sekretariaal vir die bevordering van Christelike eenheid, is van mening en vertolk die gevoelens van 'n baie groot deel van die Konsilie as hy sê dat die besluit van die Konsilie van Tiente i.s. Skrif en Tradisie nie beteken dat Gods openbaring deur twee aparte en onafhanklike bronnc. naamiik Skrif en Tradisie, na ons toe gekom hel nie. maar dat die twee gesien is as "n eenheid wat 'n ,common source”. naamlik die Evangelic, besit. By die 2de Vatikaanse Konsilie is baie oor die saak geredeneer, maar. volgens Tavard het die Konsilie dii oopgelaat: ..to hold that the entire Revelation is in Scripture while all of it is in Tradition. or even that ... a part of Revelation is in Sciipture and another part in Tradition alone". ${ }^{-9}$ Volgens Tavar! hou die Konstitusie .de Revelatione". Hfst. 3. in dat die Heilige (iees werksaam was sowel in die woordelike as skriftelike getuienis van die profete en apostels. ook in die bewaring en vertolking van die Skrifte. Daarin lề die .,indefectibilitas" van die Kerk, wat in stiat gestel moet wess on die vertroubatarheid van die leer, wat oorgelewer is. te bewaar en te vertolk en Christus hel beloof dal sy Gees die Kerk val lei in die hele waarheid (.Joh. 16:13)." Die werk van 1roloe is om op grondige Skrifeksegese lie resultate daarvan te interpreteer ,. in the context of the analogy of faith and in the continuity of the Church"s Tradition".31 Tavard verstaan die besluit van die 2de Vatikaanse konsilie so dat daar in ..mutual inherence" tussen Skrif en Tradisie is. Die een lê in die ander. In beide is dit God wat deur Christus tot ons spreek. Tradisic is eintlik maar net die vorm waarin die Bybelse Evangelie in na. apostoliese tye na ons toe gekom het onder leiding tn verligting van die Heilige Gees Daar is 'n ..radical unity" Iussen Skrif en Tradisie. Verder verklaar Tavard dat volgens seksie 10 van die Konstitusie ..De Revelatione" die ..dual unirv" van Skrif en Tradisie "n trilogie neword het, deurdat die Magisterium (die Kerk soos in die Pouslike amp verteenwoordig; S. J. v.d. W.) die outentieke interpretasie van die Evangelie gec. juis om Skrif en Tradisie te dien en nie om daaroor te heers nie. Hierdie interpretasie vind ons dan in die Cieloofsbelylenisse en ander outentieke uitdrukkinge aangaande die geopenbaarde waarheid. Tavard haal hier o.a. die volgende aan: ..It is clear. therefore that sacred tradition. sacred Scripture and the teaching authority of the Church ... . are so linked together that one cannot stand without the other and that all together and each in its oun way under the action of the Holy Spirit conuibute effectively to the salvation of souls". Die waarheid is en biy onveranderlik. maar is tog volgens die Konstitusie vatbaar vir dieper en beter begrip deur studic en verligting en kan also steeds nog ontplooi word

Tavard sî in hierdie verband dall die woord .inerrancy" (foutelousheid) deur die Konsilie verniv is, omdat dit te negatief is. Instede daarvan is bena!!ruk dat die Skrif die waarheid leer .firmly, faithfully and without error". Uit seksic II haal hy aan dat .holy mother Church. relying on the belief of the apostels (see Iohn 20:31:2 $1 \mathrm{im}$. $3: 16 ; 2$ Peter 1:19.2(); 3: 15. 16). holds that the books of both ()k। 
and New Testament in their entirety, with all their parts, are sacred and canonical because written under the inspiration of the Holy Spirit. they have God as their author and have been handed on as such to the Church herself. In composing the sacred books. (ind chose men and while employed by Him they made use of their powers and abilities. so that with Him acting in them and through them. they, as true authors. consigned to writing everything and only those things which He wanted ..." Tavard lei hieruit af dat die Bybel onfeilbaar is alleen t.o.v. sake rakendc ons saligheid. maar nie noodwendig oor sake van filosofiese of wetenskaplike aard nie. Vir ons klink Tavard se opvatting taamlik Barthiaans of Eksistensialisties. maar hy verduidelik nie wat die inplikusies van so "n ..heilsgeschichtliche" interpretasie presies inhou nie. Hy erken egier dat die Rooms-Katolieke Kerk in die verlede taamlik weggeskram het van Skrifstudie. veral uit vrees vir die sentrale plek wat dit by die Protestantse teolö ingeneen het. Min priesters, sê hy. het oor Bybelse temas gepreek. En dan verklaar hy dat dit nou juis die doel is van De Revelatione ..to restore the written and preached Word to its centrality in theology and worship"."3i

Dit wil ons voorkom asof Rome dus ook maar skipper tussen die sogenaamde (joddelike en menslike aspekte van die Skrif. as Woord van ciod. Tavard praat van in trilogie i.v.m. die Woord van die Evangelie. maar dit skyn of daar meer as drie faktore is wal saamwerk. naamlik die Bybel. die Tradisie. die Interpretasie van die Skrif. die Heilige Gees en ten slotte nog die Outeurs of Bybelskrywers. om dan nie eers te praat van die Ontvangers of Hoorders van dic Evangelie nie.

Ook Rome he die misterie van God se onfeilbare openbaring in die Skrif nie opgelos nie. Tavard en vele ander voorstanders van die Theologic Novelle kon tog weer 'n mes inkry in 'n skynbaar waterdigte formule or dic Skrifgesag. alhoewel ons $10 \mathrm{~g}$ meen dat dit nie die werklike bedoeling van Jie konsilie was om weer ' $n$ opening te laat vir Skrifhritiek nie. Daar word tog duidelik gepraat dat die hele Ou en Nuwe Testament . in their eniirety. with all their facts" heilig en kanoniek is en deur die Gees gennspireer is en dat God die Outeur daarvan is en dat dic Bybelskrywers alle dinge en alleen sulke dinge neergeskryf het as wat (jol wou gehad het. Maar o.i. sal Skrifkritiek altyd wel in woord meespreck as ons die sogenaamde menslike faktor enigsins in sclfstundigo plek gaan gee naas die Goddelike. soos wat dit helaas bv Rome. nes by dic moderne Protestantisme. volop die geval is.

Tavard verklaar dat daar tog ook wel in ontwikkeling 1.o.v. die leer van die onfeilbaarheid van die Pous gekon het. Jeurdal Vatikaan II verklaar het in seksie 25 dat. alhoewel Pouslike dekrete onfeilbaar is uit hulself (ex sese) en nic deur Ioestemming van die Kerk nie (scos tevore reals deur Vatikaan I verklaar is) dalar nou aanvaar is dat .assensus Ecclesiae nunquam deesse potest". d.w.s. dat die toestemming van die Kerk nie afwesig mag wees nie. Hy gee hierdie seksie 25 
vertaald soos volg weer: ..For when the Roman pontiff is not pronouncing judgment as a private person, bu: as the supreme teacher of the universal Church, in whom the charisin of the infallibility of the Church itself is individually present, he is expounding or defending a doctrine of Catholic faith. The infallibility promised to the Church resides also in the body of bishops, when ihat body exercises the supreme magisterium with the sliccessor of Peter. Гo these definitions the assent of the Church can riever be wanting. on acrount of the activity of that same Holy Spirit by which the whole flock of Christ Is preserved and progresses in unity of faith .3i

Hierdie uitspraak lyk vir ons egter ook maar weer baie dubbelslagtig, te meer daar die Pous kan besluit of en wanneer hy 'n Biskopssinode nodig ag en hy daarby steeds die vetoreg hou. Dit sal ook mair weer die Pous self wees wat moet uitmaak en bepaal of sy dekrete die mening van die Kerk vertolk of nie. Dit kan $h y$ ' alleen op 'n onfeilbare wyse doen.

Lukas Visscher sê dat, alhoewel die kollegialiteit van die biskoppe sterk beklemtoon is. nogtans die Pous se outoriteit in geen opsig geaffekteer is nie. Inteendeel, so vra hy, mag dit nie miskien die geval wees dat die Pouslike mag. juis deur die kollegialiteitsidee ,has become if not essentially, then at least in practise more comprehensive and dynamic?" Hy sê dat die primaat en universele jurisdiksie van die Pous gestel is ,with a clearness which can hardly be surpassed". Die primaatsgedagte in die Besluit gee Visscher soos volg weer: „The Roman Pontifex, as the Successor of Peter. whom Christ ordered to feed His sheep and lambs. enjoys in this Church of Christ. by virtue of divine institution, the greatest. complete, direct and universal power of authority: since, as the shepherd of tne faithful. he is charged to seek the hest both for the whole Church and for the individual Churches, he nas the priority (principatum) of full authority over all the churches". $3 *$

Hiervolgens meen ons dat jie feit ddt die Pous moet rekening hou met tie kollegialiteit van die biskoppe. dus hoegenaamd niks afneem van sy absolute en finale volmag oor die ganse Kerk nie: Dit bly maar nog steeds: Roma locuta. causa finita est.

\section{DIE ROOMSE KERK DIE ENIGE WARE KERK}

Daar is tot op hierdie dag nog nie 'n duimbreed afgewyk deur die Rooms-Katolieke Kerk van die idee dat hul Kerk die enigste ware Kerk is nie. Dr. Skydsgaard behandel die uitsprake van die 2de Vatikaanse Konsilie in "n artikel: . The mystery of the Church". waarin hy die ..Skema", soos dit tans op die vergadering, na herhaalde wysinge, dien in oënskou neem." Hy wys daaron dat daar o.a. sterk klem gelê word op die gedagte dat die Kerk tans op aarde 'n Pelgrimskerk is ,.in terris peregrinante". Die Kerk is "n gemeenskap van geloof, liefde en genade. Maar. sê Skydsgaard. .it is immediately added that this communion, which is the body of Christ. is identical with the Roman Catholic Church". "0 Dit is dus die éenl Kerk met twee aspek!e. naamlik die (ioddelike (I iggaam van Christus) en die 
menslike (Pelgrims en reisigers). Die Rooms-Katoiicke Kerk is deur Christus aan Petrus en die apostels toevertrou en moet dus eerder genoem word die Katolieke. Apostoliese Roomse Kerk. ..In the last analysis there is onlv one boly which has the right to the name church"."1

Ons wil hier nic ingaan op die hele kwessic van Petrus en die apostoliese ..suksessie” nie. maar alleen wys dat Rome die ander Kerke nooit as ware. volle. egte Kerke van Christus kan aanvaar nie.

Die vraag is vir ons of die hele posisic nie net mooi omgekeer moet word nie? Die Kerk is gebou op die apostels en profete en Christus as die uiterste hoeksteen. Moet ons dan nie eerder sê dat die Katolieke, apostoliese Kerk juis daur te vinde is waar daardie fondament die suiwerste bewaat is nie? Was dit nie Elia en die 7.(K)) wat die ware Israel was in die tyd van Agab nie? So gesien. kan mens alleen maar die Roomse Kerk oproep tot hekermg en om so waarlik Giereformeerd te word.

Skydsgaard meen dat hy 'n sekere verandering by die tweede Vatikaanse Konsilie bespeur het, waarvolgens Rome nie meer so baie ditgesproke is 1.o.v. ander Kerke nic. maar as't ware huiwer oor die plek wal aan hulle tocgeken moet word. Rome is dus nie meer so absoluut oor die grense van dic Kerk as 'n empiriese verskyning op ilarde nie.'" Tog bly die Kerk vir hulle ..the mysteryladen body of Christ constituted by the sacramentally understood episcopacy". Christus is op 'n baic spesiale wyse teenwoordig in die biskoppe en priesters. Hulle diens onderhou die Kerk." By Rome is die amp dus nog steeds ' $n$ besondere kategorie of kanaal waardeur die ecclesia audiens in stand gehou word. By huile ontvang die amp van die gelowiges nie die klem wat dit by die Protestantisme het nie. Hulle neem 'n bemiddelende plek in tussen (jod en die gemeente en hedien dus in dié sin die genadz aan die gemeente as plaasvervangers van Christus.

Ten slotle wys Skydsgaard laarop dat Rome nou nie meer. soos vroeër soms, dic Kerk direk met die Konikryk Gods identifiëer nie. maar dit eerder sien as die bloeisel waaruit die Koninkryk weldra sal uitbot en so ook die representan! van die Koninkryk, al is dit nie baie duidelik wat hulle daarmec beinel nie. So is daar ook nie in die Skema "n .,identification of Christ and the Church" nie." Die Koninkryk word gesien as ..the critical boundary" van die kerk. Die Kerk partisipeer aan die Koninkryk Gods maar verkeer nog in 'n paradoksale posisie."

Dit neem egter nie wey dat vir Rome die toegang tot die ewige lewe heilsnoodwendig verbonde is aan die lidmaatskap van die RoomsKatolicke Kerk nie. Hierop wys Dietzfelbinger byvoorbeek by 'n hespreking van dic Konstitusie .De Ecclesia" soos voorgelê by die tweede Vatikaanse Konsilie." Hy haal die volgende aan uit die Konstitusie: ..Eclesiam hanc peregrinantem necessarium esse ad salutem". Verder word gese dat die Kerk noodsaaklik is om orss deur die doop soos deur 'n deur in te lei ... . Quare illi homines salvari non possent. yui Ecclesiam Catholicam a Deo per Jesium Christum ut necessa- 
rium esse conditam non ignorantes tamen, ol in eam intrare, vel in eadem perseverare noluerint".

Dietzfelbinger sê dat hierdic uitspraak pertinent op die RoomsKatolieke Kerk hetrekking het en haal dan verder uit die Konstilusie aan waarvolgens dit duidelik is dat die saligherd aan die RoomsKatolieke Kerk gebonde is, behalwe alleen daar watar mense Ciod opreg soek maar uit onkunde (sine culpa ignorantes) buite dic RoomsKatolieke Kerk bl: ${ }^{4 i}$

Hy wys ook daarop dat by Rome nog slecks die neiging is $\mathrm{om}$ Christus en die Rooms-Katolieke Kerk gelyk te stel. ondat Christus volgens Rome vir alle mense gesterf het en (iod se genade hom dis eintlik tot alle mense uitstrek. Insoverre rhristlis on alle mense aanspraak maak, het Hy ook die middele om vir alnal die heil te beskik. maar omdat en sover as wat Christus deur die Rooms-Katolieke kerk vervang word, is die heil dan weer beperk tot lidnaatskap van die Roomse Kerke. Dietzfelbinger meen dat daar iets van 'n tweeslagtige houding in die Konstitusie oor die kerk is. Waar die Konstitusie (soos ook Paulus VI in sy openingstoespratak by die tweede sitting) van Christus priat. praat dit tegelyk van die Rooms-Katolicke Kerk. Om'n Christen te word beteken Jus net mar on Katoliek te word." Daar is $g^{\prime} n$ ander moontlikheid nie.

Dit is Jus ten slotte nie die Evangelie nie, matr die Kerk wat ons vrymaak en salig maak. In 'n stuk oor ..The Church and the Churches"': het Niebuhr vroeër enkele hehartigenswaardige dinge gesê. Hy wys darop dat daar gevaar is dat die evangeliese waarheid verlonker kan word in die pogings tot Kerklike eenheid en sề dat daar behoefte is om ' $\mathrm{n}$ keer terug to keer na die historicse afskeidsbeweginge om die suiwerheid van die evangelie te herstel. Hy wys daarop dat Rome byvnorbeeld ' $n$ indrukwekkende eenheid bewalar het. maar dit alleen kon doen deur twee ketterve in te voer. Die én ketiery was on die Kerk te verhef as dic voortsetting van die inkarnasic van Christus en dus in wese iets Coddeliks en as Middelares van die heil. ..This heresy was to obscure the chasn between the human and the divine". En die tweede kettery vloei daartit voort. naamlik 'n leer van verdienstelikheid waar die mens met die rrappe op moet klin na die saligheid. So is die mens dan van die Kerk (Priesters) afhanklik on die heil te verkry; ..a very vexatious and pretentious priesthoor. pretending to have dominien over all the nations in the name of "hrist"."

Niebuhr sê dat daar 'n onversoenlike opvalting oor die Kerk is by Rome en by die Protestantisme. Vir die Protestantisme is die Kerk alleen heilig omdat en vir sover as wat dit (iol se geregtigheid en genade bemiddel deur die Evangelieverkondiging. Vir Rome is die Kerk .,the extension of the Incarnation" en besit gevolglik die heiiigheid van Christus in haarself.:1

A! stel Niebuhr die salak hier to simplistie; in die taal van die Dialektiese Teologie, is daar og wel iets in dat Rome te weinig esgatologies dink en die Koninkryk (jods sien as voorlopig gerealiseer in die Rooms-Katolieke Kerk. Frakties is dic Pous dan oon veel meer as stadhouer van Christus. om nic eers te sê in Boolskapper. Aankon. 
diger of Ciesant van Christus me. Die misticke Christus leef. spreek on werk in die Pous. Die Pous is Christus self in bedekte gestalte.

\section{IS ROME AI.I.EEN DIE WARE KERK?}

Prof. F. Schlınk, wat as walasnemer die 2de Vatikaanse Konsilie bygewoon hel, wys daarop dat in die Dekreet oor Ekumenisme, wat ind 1964 aanvaar is, van die nie-Roomse Kerke praat as ...kirchliche (jemeinschafter". omdat daar ook wel ..elemente" van die ware Kerk te vinde is en dat. waar Rome in die verlede afsydig gestan het teenoor die Ekumeniese Beweging. hulle nou 'n beroep doen op die Roomse lidmate en veral die biskoppe on vwerig daaraan deel te neem." Verder wys Schliık dlaarop dal. terwyl in die Skema oor die Kerk lie Roons-Katclieke Kerk sonder meer met die één. heilige, algemene christelike Kerk geidentifiseer word. daar in die Skema oor die Ekumenisme wel gepraat word van nie-Katolieke Kerke $(\mathrm{Gr}$. Ortolokse Kerk) en Kerklike (iemeenskappe (Protestanse Kerke). Hier word aanvaar dat nie alleen die doop nie. maar ook baic ancier genadewerkinge in die nie-Roomse Kerke 'n band met Christus vorm. Maar ook waar in die Kirchenkonstitution (hesluit oor die Kerk) die woordjie .est" gebruik is (Die Rooms-Kallolieke Kerk is die ware Kerk) word nou gesê: ..Haec ecclesia . . . .,uhsistit" in Ecclesia Catholica". Hicrmee, meen Schlink is die moontlikheid gegee dat die Ina Sancta se grense ook tot buite die Roomsc Kerk mag strek. Dit alles word egter so gesien dat die nie-Roomse alleen maar enigermate deel het aan die skat van genade wat eintlik alan die Roomse Kerk behoort. Alleen die Rooms-Katolieke Kerk het d:e .Fülle der Gnade und Wahrheit"

Schlink wys verder daarop dat Rome die nie-Roonse Kerke nog ie veel sien as Kerke soos hulle was voor die stigting van die Wêreldraad. en vergeet dat hulle as lidkerke van die Ekumeniese Raad (W.R.) ..in einer mannigfach bewáhrten und ständig wachsenden Gemeinschaft des Gebens und Neinmens zusammenleben und hierdurch neue öffnungen und Frägungen erfahren"." Die W.R. het dus blykbaar ' $n$ uitwerking op die lidkerke om hulle plasties en plooibaar le maak. sodat hulle allerlei invloede van mekaar ondergaan. Wat Schlink hier sê is ongetwyteld waar. en lie vrdag is dan of dit vir die Ceref. Kerke ten goede kan kom on hulle so te laat beinvloed deur byvoorbeeld Anglikaanse. Ortodokse. Vrysinnige ten eventueel uok Roomse) invloede? Speur ons nie alreeds die ..winde van verandering" byvoorbeekl in die Ceref. Kerke van Nederland, wat nou geen beginselbesware meer het om by die W.R. aan te sluit nie?

Schlink wys verder daarop dat in die besluite oor die Ekuméne die Pous self op dic laaste oomblik sekere wysiginge aangebring het wat die Konsilie moes aanvaar en wat in sekere verswakking beieken het onr dic uitsprake i.v.m. nie.Roomse Kerke. Hiervan is een van die helangrikste dié wat geŝ́ het: ..Spiritu Sancto movente. in ipsis Sacris Scripturis Deum inveniunt sibi lecpuentem in Christo". Dit is nou verander na: .Spiritum Sanctum invocantes, in ipsis Sacris Scrip. luris Deum inquirunt quasi sibi loyuentem in (hristo". Hulle word 
Jus nie deur die (iees beweeg nie, maar hulle roep die (iees an. Hulle rind God nie in die Skrifie nie. mair soek God in die Skrifte. asof $\mathrm{Hy}$ in Christus spreek. In 'n voetnool wil Schlink aantoon dat die quasi nie so verstaan moet word nie. maar sy verduideliking lyk vir ons swak si

Ten slotte wys Schlink dan daarop ciat volgens die Konstitusic or Ekumenisme dit daarop neerkom dat in dic Roomse Kerk die Ekumeniese Kerks reed voorhande is en dat die ander Kerke dus die Roomse Dogma-Pous moet aanvaar. Dis dan in teëstelling met die .ruimere" opvatting van die W.R.. waar almal mekaar as Kerke op 'n gelyke voet ontmoet en waar selfs g'n vorm van ..proselietemakery" van die een teenoor die ander toegelant word nie. Dit skyn of Schlink hier nie so seker is watter vorm van ekumenisme die deurslag moet gee nie, aangesien Rome daren! nog aan hulself glo. terwyl by die W.R. die Kerkgedagte gerelativieer word, in beginsel altans. Want Schlink sê: ..Aber sind wir nicht heute in Jer Situation, dasz jeder i)kumenismus, auch den der evangelisch-lutherischen Kirche. dringend einer weiteren Klärung bedarf?"

Ons insiens is dit presies hier waar ons swakheid as Protestante teenoor Rcme inkom. Die Protestantisme het sterk gestaan solank hulle die Skrif as gesagsinstansie teenoor die Roome ..Papa dixit" gestel en gehandhaaf het. Met die Bybel in die cen hand kon I.uther. om dit so te sê, met sy ander hand die Pouslike ..Bul" In die vuur gegooi het. Mar by die moderne Protestantisme is die saak omgekeerd. Ons het ons losgemaak van die gesag van die Skrif en dan is die gevoly onvermudelik dat die Protesiantse wêreld sal terugkeer soos die hond na sy eie uitbraaksel, terug in die arms van die Pous. Sonder gesag kan dis mens nie lewe nie, veral waar dit die dinge aangaande sy ewige heil of wee betref.

Paolo Ricca, predikant van die Waldensiese Evangeliese Kerk in Italië, het in deeglike studie gemaak van die Rooms-Katolieke Konsilie se besluit: .De Oecumenismus" en is van mening dat daar wel 'n sekere wending te bespeur val t.o.v. die Roomse houding van vroeër, naamlik dat die nie-Roomse Kerke nou nie meer net as afgedwaaldes gesien word nie. maar eerder as Kerklike gemeenskappe wat wel sekere Christelike waarhede of :vaardes besit. maar wat eintlik eers as integrale deel van die Roomse Kark tot hulle reg kan kom. Dit gaan dus nie meer net bloot daarom dat sulke Kerke na Rome moet terugkeer nie, maar eerder dat hulls hul ware self hinne die Roomse Kerk moet vind. "The goal is a grandiose Christian syn!hesis". Om hierdie sintese te verkry is Ronie hereid ..to broaden its own theological, liturgical and organizational frontiers to the point needed if it is to gather into its unity the authentic Christian values of the Orthodox and Protestant Churches, as well as some of the values found in the non-Christian religions"::

So skyn dit dan of ..moeder" Rome bereid is om in die ..moederarms" of -.,skoot" weer al haar afgeskeie ..kinders" on te neem. as „modaliteite" binne die Roomse Kerk. Ricca sê: .The spirit of synthesis is the very essence of Roman Catholicism". En hy verklaar 
lat dit nou nie meer soseer gaan on integrasie van die ander Kerke nie, as 'n sintese met hulle, hinne die Rnomse Kerk. Ricca sê dat ons in hierdie hele salak meer 'n sekere Reformisme moel sien eerder as 'n egte Reformasie van die Roomse Kerk. Verder wys hy daarop dat die besluit De Oecumenismus geïnterpreteer moet word in die lig van dié oor die Kerk (De Ecclesia), en in daurdie besluit word die Protestantse Kerke nie genoem Kerklike gemeenskappe nie recclesial communities). maar ..pcclesiastical communities". dus iets Kerkagtigs. Dit dui meer op die sosiologicse karakter as die waarlik Kerklike karakter.:- Die Protestantse Kerke is dus nie Kerke in teologiese sin nie.

Hierby mag ons wel daarof let dat die 2de Vatikaanse Konsilie op die laaste sittingsdag. 7 Desember 1965. tegelykertyd met die besluit van die Patriargaa! van Konstantinopel. besluit het om wodersyds die Ekskommunikasiebulle van 1054 te annulleer, waarby die Pous en die Patriarg mekaar omarm het. ${ }^{\text {an }}$ Rome het daarmee die Ortodokse Kerk aanvaar as Kerk van Christus, wat hy nog nie met die Protestantse Kerke gedoen het nie. Intussen het die Pous (Paulus VI) te kenne gegee dat Rome t.o.v. die ampsbediening in die Anglikaanse Kerk nog staan by die Dekreet van 1896, jeur l eo XIII. waarby die Anglikaanse wyding as nul en nietig verklaar is. Nogtans het die Pous verklaar dat die wedersydse amptelike erkenning van die Anglikaanse en die Ou-Katolieke Kerke. die posisie enigsins verander het en dat die verhouding nou heroorweeg mag word, insoverre dit gaan om die erkenning van die ampte in die Anglikaanse Kerk." Rome weel dus wel om toeskietlik te wees as hy montlik via die Anglikaanse Kerk die ander Protestantse Kerke in sy magsfeer kan betrek.

\section{VERANDERING BY ROME?}

Professor Susse skryf in ..The Reformed theological review" in 'n artikel: .After the Council." dat daar veral twee sake van belang is wat op die 2 de Vatikaanse Konsilie gebeur het. naamlik dat die volkstaal nou ook in die liturgie gebruik kan word en dat dic biskoppe nou in 'n soort kollegialiteit met die Pous saamverbind is."1 Soos die Pous beskou word as die opvolger van Petrus. so word die biskoppe heskou as dic opvolgers van die apostels. Sasse sè dat daar 'n ,lack of clarity" in hierdie bepaling is en dat die doel skyn te wees on die kloof enigsins te oorhrug wat daar tussen die Pous en die biskoppe ontstaan het by die Iste Vatikaanse Konsilie.

Verder wys hy daaron dat daar hierdie keer nie weer anatemas uitgeslinger is nic. maar dat daar eerder toenadering tot die ..seperatel brethren" gesoek is. Ook vind Sisse daar iets goeds in dat die Roomse Kerk wil vashou aan die vastigheid van die geloof wat eenmaal aan die heiliges oorgelewer is, alhoewel hy hetwyfel of hulle die geloof wel op die regte manier vasgehou het. ..purely taught and preserved without violation".:"

Sasse meen dal die nuwe Rome nie meer die Skrif naas die tradisie stel as bron van openbaring nie, maar dat dit dic inhoud van alle 
tradisie wesenlik in homself bevat. ..The Catholic (hurch of today is a Bible Church as it has not been for centuries" Dit is die één Woord van God wat tot ons kom as Skriftuur en Tradisie. Die Skrif self is eintlik maar die neergeskrewe deel van dic Tradisie. ${ }^{63}$ So is byvoorbeeld die hele Maria-leer 'n wesenlike deel van God se openbaring. maar wat grotendeels deur die buite-Skriftuurlike Tradisie na ons gekom het. maar tog as deel van God se geopenbaarde Woord Die Heilige Skrif alleen is dus nie die absolute norm van die waarheid nie.

In hierdie verband moet ons egter opmerk dat o.i. hier 'n spel gespeel word met die Woord van God, wat alleen tot oëverblinding kan lei. Rome het ook op die punt van Skrif en Tradisie g'n wesenlike verandering ondergaan nie. Berkhouwer. wat self 'n waarnemer by die Konsilie was. verklaar dal. op spesiale wens van die Pous, die woorde: „nie deur die Skrif alleen nie", ingevoeg is in die besluit insake Skrif en Tradisie. Die besluit lui Ian nou so (soos weergegee deur Berkhouwer): ..De heilige overlevering en de Heilige Schrifi zijn derhalve nauw verbonden en hebben aan elkaar deel. Want beide stromen voort uit dezelfde goddelijke oorsprong, vloeien als 't ware ineen en zijn op hetzelfde doel gericht. De Heilige Schrift inımers is het spreken van God, voorzover dit onder aandrift van de Geest schriftelijk wordt vastgelegd. de heilige overlevering geeft het Woord Gods, door Christus de Heer en de Heilige Geesi aan de apostelen toevertroud, ongerept door aan hun opvolgers. opdat zij dit, in het licht van de Geest der waarheid door hun verkondiging trouw bewaren. uiteenzetten en verbreiden. Vandaar dat de kerk haar zekerheid over al het geopenbaarde niet put door middel van de Schrift alleen. Daarom moeten beide - overlevering en Schrift - - met gelijke toewijding. vroomheid en eerbied aanvaard en vereerd worden " ":

Berkhouwer meen dat die band tussen Skrif en Tradisie wel nouer gelê is deurdat nie meer gepraat word van uit (as twee aparte bronne). maar van deur. Tog sê hy, wou die Pouss die ..sola scriptura" van die Reformasie duidelik afwys.

Dis duidelik dat, hoc ons die saak ook al beskou. Rome nog steeds sekere ..waarhede" alleen met die Tradisie kan dek. al is Die Waarheid, soos deur God geopenbaar. wel één. en al staan Skrif en Tradisie daarom ook nie los van mekaar nie. Wat nie klaar en duidelik uit die Skrif bewss kan word nie, is nog altycl veilig gestel deur die Tradisie. Inderdaad, Rome verander nie.

\section{VERWYSINGS}

1. Intern. Kirchliche Zeitschrift. Jrg. 56, no. 4. p. 250 .

2. Vgl. De Reformatie. Jrg. 41 .. no. 16. p. 127.

3. Vgl. Die Brug. Februaric 1966.

4. Vgl. ..Der feste Grund" Maart. 1966. p. 14.

5. Ibid. (Der feste Grund).

6. Vgl. .The ecumenical Review", Vol. 18, No. 1. p. 35.

7. Id.: p. 36 .

8. .Christian Minister" Julic 1966. p. 24 
9. ..La Civita Catholica”. Maart 6. 1965, p. 8.

10. ..The new (atholic synthesis and the function of Protestantism". in The Reformed and Presbyerian World, Vol. XXIX. no. 1. p. 6.

11. Vgl. .Vatican Council $I 1$ and the people of (jod" in The Reformed and Presbylcrian World, Vol. XXIX. no. 1, p. 14

12. Id., p. 15.

13. Id.. p. 17.

14. Id., p. 19.

15. Id.. p. 20 .

16. Verskyn by J. H Kok. Kampen 1964. Vgl. veral hfst. II en IX.

17. Kyk Die Brug, Iunic 1966 pp. 7-8.

18. Kyk Cieref. theol tydschrifı, 4 Nonember 1966. p. 193

19. Id. p. 195. v.

20. Id., p. 198.

21. Id.. p. 199

22. Ibid.

23. Id., p. 201

24. Id. a angehaal. p. 202

25. Kyk Intern. Kirhliliche Leitschrilt, Apr-Jun 1966, p. 65

26. Idem. p. 67.

27 Idem, p. 68.

28 Idem. p. 74.

29. .Commentary on de Revelatione". in Jomrnal of Ecumenical Simdies, Vol. 3. no. 1. p. 7 .

30. Art. uit Journal of Ecumenical Sindies, soos tevore. p. 9

31. Idem. p. 10 .

32. Idem, p. 19 .

3.3. Idem. p. 23

34. Idem. p. 26 .

35. Idem, p 27.

36. Idem. pp. 29-30.

37. Journal of Ecumenical Surdies, Vol. 3. no. 1. n. 33. .Commentary on de Revelatione".

38. Ecumenical Review, Vol. XVIII. no. 2. p. 158.

39. Vgl. Journal of Ecumenical Studie's, Vol. 1. no. 3.

40. Idem. p. 409.

41 Ibid.

42. Idem, p. 410.

43. Idem, p. 415.

44 Idem. p. 418.

4?. Idem. p. 420.

46. In Kerugma en Nogma, Jig. I1. Hft 3.

47. Idem, p. 173

48. Jdem. n. 176.

49. Applied Christianity, p. 265 e.s.

50. Idcm. p. 336 .

51. Idem. p. 342.

52. In Kerugma ('ll Mogmu, Irg 11. Hft. 3. p. 183 e.v.

53. Idem. p. 186.

54. Idem. p. 189.

55. Idem. $\mathrm{r} 192$

56. Idem pp. 193.194.

57. ..Some reflection on De Oecumenismus". in The Reformed Preshylerian World vol. XXvill. no. 7. p 307.

58. Idem. p. 309

59. Imern. Nirch!iehe Zerischrift, Apr-Jun. 1966, p. 112

(o). Idem. p. IIs.

61. The Retormed Thesl. Review, Vol. XXV. no. 1, p. 3.

62. Idem. p. 7

63. Idem. pp. 11-12

64. Cicref. Ifakblad. Jrz. 22. no. 13. voorblad 